
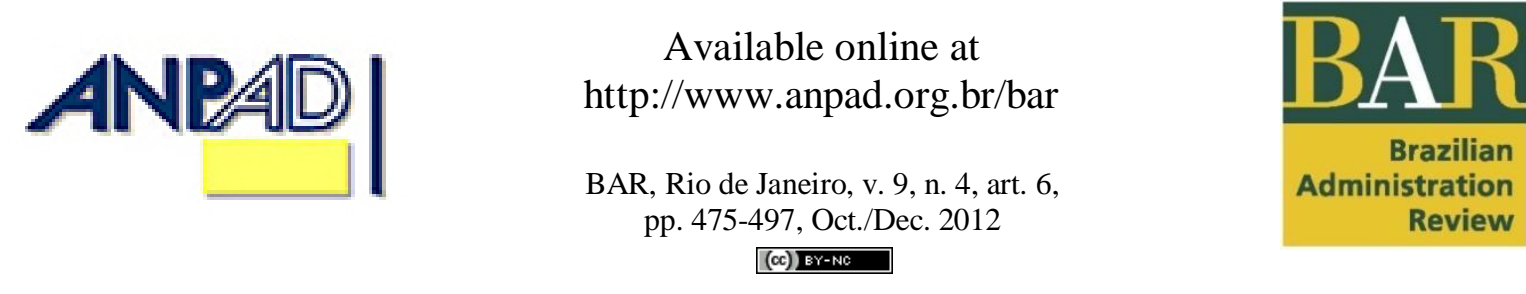

$((c)$ EY-NC

\title{
The Role of Interpretation in the Internationalization of Smaller Brazilian Firms
}

\author{
Rene Eugenio Seifert* \\ E-mail address: resj@up.com.br \\ Universidade Positivo - PMDA/UP \\ Curitiba, PR, Brazil. \\ John Child \\ E-mail address: J.Child@ bham.ac.uk \\ Birmingham Business School - University of Birmingham \\ Birmingham, UK. \\ Suzana B. Rodrigues \\ E-mail address: srodrigues@rsm.nl \\ Universidade FUMEC; Rotterdam School of Management - Erasmus University \\ Belo Horizonte, MG, Brazil.
}

* Corresponding author: Rene Eugenio Seifert

Av. Prof. Pedro Viriato Parigot de Souza, 5300, Campo Comprido, Curitiba, PR, 81280-330, Brazil. 


\begin{abstract}
This study considers how decision-makers in smaller firms interpret the means and conditions of internationalization, and how different modes of interpretation are likely to inform action choices in this process. Drawing on 58 qualitative interviews with the leaders of Brazilian small and medium-sized enterprises (SMEs) in the clothing industry located in the state of Paraná, the results support the contention that different understandings given to the means/conditions of internationalization are associated with different action choices. More specifically, the results indicate that: (a) interpretation changes the criteria and parameters by which rational choices on internationalization are made; (b) a comprehensive explanation of internationalization on the basis of situational characteristics is likely to be inconclusive without taking into account decision-makers' interpretations; (c) particular meanings given to internationalization are likely to inform choice in different ways, (d) managers act on the basis of their inter-subjectively negotiated, shared and sustained reality; and (e) investigative proximity with practitioners is pivotal in order to comprehensively account for their interpretations.
\end{abstract}

Key words: internationalization; interpretation; strategic choice; organizational action; theory development. 


\section{Introduction}

Most research on internationalization has neglected the role of an entrepreneur's cognitive mechanisms on organizational choice and action in this process (Acedo \& Florin, 2006; Zahra, Korri, $\& \mathrm{Yu}, 2005)$. Drawing on the view that organizational action is not independent from an actor's interpretation (Bartunek, 1984; Child, 1997; Daft \& Weick, 1984) in this study we investigated (a) how decision-makers in smaller firms interpret the means and conditions of internationalization, and (b) how different modes of interpretation are likely to inform action choices in this process. This enabled us to question whether internationalization can be understood as a strategic action that is objective and independent from actors or whether it should be viewed as a phenomenon that is informed by their interpretation or understandings.

The results of the study show that the meanings decision-makers attribute to internationalization as an activity, and as a strategy to enter and operate in foreign markets, have a fundamental role in their action choices and therefore should not be ignored in theorizing on the subject. The study contributes to the development of an interpretative perspective on internationalization and to the theoretical renewal and advancement of the field.

The following section reviews how internationalization has typically been theorized, and considers the role of managerial interpretation in this process. We next describe the scope and method of the empirical investigation followed by the presentation of its principal findings. We then discuss how our findings inform prevailing theorizing in the field and conclude with lines for further research.

\section{Theoretical Considerations}

Internationalization is typically characterized by some form of international involvement or engagement in cross-border activity, such as foreign trade and/or investment (Boddewyn, 1997). Prevailing theories attempting to explain such phenomenon have been conventionally classified into two broad perspectives, namely economic and behavioural (Andersson, 2000; Burgel, Fier, Licht, \& Murray, 2004; Johanson \& Vahlne, 1990; McDougall, Shane, \& Oviatt, 1994).

Economic theories presume that events that typically characterize internationalization, such as exports, imports, and foreign direct investment, are outcomes of rational calculation put forward by those with decision-making power in order to maximize a firm's revenues or profits. Decision-makers are depicted as utilitarian centres of calculation capable of identifying opportunities and evaluating advantages within their business situation and, on this basis, adopting the course of action that would maximize the utility of fixed goals. Hence, there is not necessarily a link between the events that characterize internationalization. Such assumptions can be easily identified in theoretical approaches such as: (a) the monopolistic advantage theory (Hymer, 1976); (b) the internalization theory (Buckley \& Casson, 1976); (c) the eclectic paradigm (Dunning, 1980); and in the (d) the resource-based view of international business (Peng, 2001).

By contrast, behavioural theories presume that rather than the result of independent and rational decisions to maximise profit, internationalization is a path-dependent learning process, rationally limited, and whose goals are much more complex than the mere pursuit of profit maximization. Scholars within this perspective presume that internationalization is typically determined by knowledge-learning mechanisms, network relationships, and a number of contextual variables within a firm's situation. Among these are firm size, age, risk-taking behaviour, uncertainty levels, psychic distance, prior experience, and so forth. Examples of theories which represent this view of internationalization are those which focus on the foreign investment decision process (Aharoni, 1966), the classic Uppsala model of internationalization (Johanson \& Vahlne, 1977, 1990), the innovation adoption models (Bilkey \& Tesar, 1977; Cavusgil, 1980; Lim, Sharkey, \& Kim, 1991; Reid, 1981), the 
network approach of internationalization (Coviello \& Munro, 1997; Johanson \& Mattsson, 1988; Johanson \& Vahlne, 2006) and the evolutionary theory of the MNE (Kogut \& Zander, 1993).

In economic theorizing, those with power to decide are presumed to be capable of rationally assessing, measuring and evaluating an objective and independent reality. It is assumed that as rational people, decision-makers respond to information about the environment in a similar manner, by calculating the risks and utilities associated with a set of alternatives. Ultimately, interpretation is bypassed and theorizing proceeds without the need to recognize how decision-makers give sense to their situation. In particular, how decision-makers understand the means and conditions of internationalization practice, how they interpret the potential utility of their actions, or make sense of their firm's resources is deemed irrelevant. Similarly, in behavioural theorizing, although internationalization is characterized in terms of uncertainty and the limited use of rationality, theorists presume that actors have the ability to perceive and learn about an independent and objective reality in their minds. Hence, similar to economic theorizing, it neglects the fact that human beings and their world are not independent, but rather inextricably related (Berger \& Luckmann, 1966; Schutz, 1972; Weick, 1969). Most theories within this perspective overlook the possibility that both the knowledge learned through practical experience and the situational forces influencing internationalization are interpretative constructions.

This is not to deny that many studies have considered managerial perception when investigating internationalization phenomena. For example, Calof and Beamish (1995) considered managerial perception when explaining why firms change modes of foreign operations. Manolova, Brush, Edelman and Greene (2002) considered environmental perception when explaining the internationalization of small firms and Oviatt and McDougall (2005) investigated the mediating role of entrepreneurs' perceptions when modelling the speed of internationalization. Although these studies have contributed importantly to our knowledge of internationalization, the emphasis of this study on interpretation aims to incorporate an ontological distinction. It assumes that interpretation and perception are not exactly the same. With some exceptions (Seifert \& Machado-da-Silva, 2007), studies that take managerial perception into account do not automatically presume that reality is intersubjectively constructed. Perception, as Aristotle said, is a matter of the senses. Thus, it does not necessarily preclude an objective view of reality; which ultimately could be perceived in different ways. Interpretation, by contrast, as considered within an interpretative perspective of organizational action, is an inherent element of social action (Alexander, 1988; Daft \& Weick, 1984; Gioia \& Chittipeddi, 1991; Sandberg \& Targama, 2007). It encompasses an inter-subjective process whereby reality is given meaning or significance (Alexander, 1988; Blumer, 1998; Daft \& Weick, 1984; Schutz, 1972). It is underlined by the idea that what is known about the world is never a mere subjective representation or perception of reality, but instead the result of complex cognitive processes such as selection, sorting, manipulation, conversion, typification and imagination which are collectively activated, sustained and transformed (Sandberg \& Targama, 2007; Spender, 1998). On the one hand this suggests that any given experience can be understood in multiple ways, as studies considering the role of perception would argue. Nevertheless, on the other hand, it also considers that forces and characteristics of an organization's situation are neither external to decision-makers nor can be directly accessed and affected by their action choices. Rather, interpretation encompasses the process which produces and reproduces the meaningful framework for action and choice.

This understanding has at least four major implications for theorizing. First, that decisionmakers do not proceed in a reality of objective facts, but rather in a reality of inter-subjective, collectively activated, sustained and transformed interpretation (Berger \& Luckmann, 1966). Second, that interpretation conditions which information should receive attention and in so doing may both facilitate as well as limit attention to relevant changes in the situation (Daft \& Weick, 1984). Third, that interpretation orients how internal and external data and stimuli will be understood (Bartunek, 1984). Fourth, that interpretative processes are responsible for creating the meaningful framework that inform and direct organizational choice and action (Child, 1997; Silverman, 1978).

In this study we take these arguments into account when investigating how decision-makers interpret the means and conditions of internationalization within their situation. Drawing on Parsons 
(1968), we consider the means and conditions of internationalization to comprise, respectively, the controllable and uncontrollable elements which are included in the assessment of action choices, and which are distinguished from its purposes or ends. In the following section we describe the scope and methodology of our investigation.

\section{Scope and Method}

We decided to study internationalization among the leaders of SMEs operating in the clothing industry of the State of Paraná, Brazil. The reasons for choosing this setting were, first, that several authors have identified a need to better understand the internationalization of smaller organizations and particularly those from emerging economies (Bell, McNaughton, Young, \& Crick, 2003; Child \& Rodrigues, 2005; Hitt, Bierman, Uhlenbruck, \& Shimizu, 2006). Second, investigating internationalization among SMEs located in countries like Brazil, which enjoy a large domestic market, a history of economic protectionism, and a context where firms a not likely to internationalize (Rocha, 2003), suggested a fruitful ground for theory development. In particular, we considered that some aspects of internationalization in this context would not necessarily conform to the assumptions of conventional international business theory. The choice of the clothing industry was based on the fact that the industry has been characterized by internationally-driven fashion. It is an industry where small firms are abundant, and more important, one in which where small scale production does not necessarily limit value-adding activities in terms of design and differentiation. The focus on the State of Paraná addresses the theoretical importance of investigating firms operating in similar geographical conditions and as well as meeting practical considerations of access, time and funding. It is worth mentioning that Paraná is the second largest producer of clothes in Brazil, and that SMEs in Brazil are considered to be firms with no more than 500 employees.

Sampling procedures were theoretically driven (Eisenhardt, 1989; Glaser \& Strauss, 1967; Ritchie, Lewis, \& Elam, 2003). They attempted to enable comparison about how different decisionmakers understand the means/conditions of internationalization. The sample included SMEs actively engaged in foreign operations, occasional exporters or importers, and those with no international involvement. In addition, it included SMEs with different firm and managerial characteristics. A sampling matrix was constructed based on information gathered through a prior survey of all SMEs in the sector. This offered a comprehensive view of the firms' international involvement and served as a basis for theoretically sampling among them. The following variables were included in the sampling frame: (a) engagement, speed, and pace of internationalization; (b) firm size; (c) firm age; (d) decision maker's prior international experience; (e) export intention; and (f) knowledge of foreign languages. With this approach we aimed to maximize sampling variance in order to account for the maximum range of interpretations attached to internationalization. Sampling was carried until data saturation, in terms of units fulfilling the criteria established, was attained. In total we interviewed the owners, hereafter referred as decision-makers, of 58 SMEs in all major regions of the State of Parana. Within this sample, 34 firms had some experience of international trade: most of these were exporting, though some were importing. The other 24 firms had never engaged in any international trade or foreign investment. The Appendix provides a comprehensive profile of the firms.

Forty-five out of 58 interviews were digitally recorded. When digital recording was not possible, notes were taken and relevant topics reconstructed within 24 hours as recommended in the specialized literature (Bourgeois \& Eisenhardt, 1988; Gioia \& Thomas, 1996). After briefly establishing the history and profile of the firm, the interview developed as a conversation on the topic of internationalization. It was informed by an interview guide including general and open-ended questions about (a) the firm's international involvement or lack of it; (b) the decision-maker's view of foreign operations; (c) requirements of internationalization; and (d) international aspirations for the firm ${ }^{(1)}$. The interview guide facilitated the recognition of meanings informing internationalization and ensured that similar topics were covered with all participants (Burgess, 1984). Nevertheless, the guide was not a script applied mechanically during the interviews. Rather it attempted to give focus to the 
interview and to keep the conversation flowing. Care was taken in order to make interviews sufficiently flexible to permit topics to be covered in the order most suited to the interviewee, to allow areas of interest to be explored in depth, and new issues emerge. In addition, each area was explored through what, who, where, why, when and how probes (Legard, Keegan, \& Ward, 2003; Silverman, 2006; Yeung, 1995). This is in line with the exploratory and inductive nature given to the interviews. A typical interview took about 45 minutes.

The first step in analysis was intended to augment our familiarity and knowledge of the data. It entailed listening to every interview and writing summaries (Eisenhardt, 1989). This was essential for generating theoretical insights at later stages of the analysis (Pettigrew, 1990). The second step was to assign codes to the data (Corbin \& Strauss, 2008; Miles \& Huberman, 1994). This process involved inductive and deductive procedures at different levels of abstraction aimed at identifying major categories or themes regarding decision-makers' understandings of the means/conditions of internationalization. Open and axial codes (Glaser \& Strauss, 1967) were assigned in the interview summaries, notes and audio files with the assistance of the software package NVivo 8 . They focused on the properties, conditions and consequences of each category coded. This process involved considerable experimentation, much reflection, and comparison. It finished when codes and categories were sorted, compared and contrasted until saturated; i.e. when generated codes could comprehensively account for the core grounded categories representing decision-makers understanding about the means and conditions of internationalization. The content assigned to each category was then reviewed and discussed by the authors. In order to maximize the reliability of the coding procedures, two external auditors were recruited as co-analysts to check the coding reliability of approximately $10 \%$ of the data; neither had any prior knowledge of or contact with the data. They were trained in the analytic framework and were asked to code interview samples that had not been prepared or groomed. There was a coding reliability of between $75 \%$ and $80 \%$ across coders. Some discrepancies arising from the understanding and interpretation of the raw data were observed. Inconsistencies were discussed and a single convergent interpretation agreed upon. On this basis, deviant codes were revised accordingly.

The final analytical step involved displaying and drawing conclusions. It focused on how meanings assigned to the purposes of internationalization could have informed organizational action towards internationalization, namely: domestic operation, occasional or active internationalization. Drawing on the previous survey that informed sampling, firms were considered 'active' internationalizers when during the last financial year of operations, they exported or imported and none of these operations had been established for the first time in the year that the study was conducted. Firms were considered occasional internationalizers when, although having established foreign operations in the past, they had only transacted in the domestic market during the previous financial year. We took this one year gap to indicate whether a firm could be characterized as occasional or active internationalizer.

The analysis consisted of drawing a matrix where core categories of meanings regarding the purposes of internationalization as expressed by decision-makers were crossed with cases (firms) into rows and columns as suggested by Miles and Huberman (1994). A binary coding notation was then used: where a particular meaning was identified in a participant's account, the number $\mathbf{1}$ was assigned in the respective cell. Meanings not present were noted as $\mathbf{0}$. The sample size was deemed adequate to use statistics as a means of aiding the exploration. During this stage, the analytical procedures drew largely on the tenets of content analysis (Krippendorff, 2004). Two simple statistical procedures were used: (a) frequency count, and (b) Phi measure of association between binomial variables (Field, 2005). Counting frequencies made it possible to recognize modes of interpretation occurring more often, and to further give sense of the data as a whole (Silverman, 2006). The Phi test enabled exploration of the strength of association between meanings and international action, and to recognize patterns in the data. Certainly, this quantitative approach to qualitative data analysis is not without methodological limitations and epistemological concerns. Silverman (2006, p. 51) notes that many authors claim that "no good qualitative researchers should dirty their hands with numbers". However, he contends that simple counting techniques offer the means to investigate qualitative data further, in 
particular when working with large data sets. In his words qualitative researchers "cannot afford to live like hermits, blinded by global, theoretical critiques to the possible analytical and practical uses of quantification" (Silverman, 2006, p. 52). Ultimately, it is important to recognise that in this approach, categories of meanings and their assignment to participants are largely dependent on the researcher's inference. The constructionist inductive approach to the categorization of meanings means that categories counted were ultimately the ones determined by the researchers.

Triangulation was applied at each stage of the investigation in order to enhance validity and reliability of the findings. During data collection, it was attained by using alternative and complementary sources of evidence in addition to the qualitative interviews; in particular observation, note taking, and secondary archival information about the firms. The conduct of the research at multiple sites further enabled the researchers to triangulate, cross-check and corroborate findings across cases (Eisenhardt, 1989; Yin, 2003). During data analysis, triangulation aimed to enhance the credibility of this process by the means of alternative explanation building, and as earlier noted crosschecking categories generated with two external analyzers not involved with the fieldwork (Miles \& Huberman, 1994). Finally, qualitative relationships were triangulated with the quantitative counting of events and measures of association which enabled spurious qualitative conclusions to be avoided (Seale \& Silverman, 1997; Selltiz, Wrightsman, \& Cook, 1976).

\section{Findings}

Our investigation suggests that the means/conditions of internationalization as interpreted by the decision-makers interviewed can be classified into five main categories, namely: (a) quantities involved; (b) mode of competition; (c) differences between foreign and domestic operations; (d) risk and uncertainty of operations; and (e) legitimacy of international activities. In addition, it indicates that decision-makers may interpret internationalization in rather different ways. Precisely, their rationales offered a basis for the analytical distinction of at least two alternative modes of interpretation in each category. Table 1 indicates the means/conditions characterizing alternative modes of interpretation, the frequency of their incidence, and presents illustrative quotations for each category. 
Table 1

Variants of Interpretation Regarding Means/Conditions of Internationalization

\begin{tabular}{|c|c|c|c|c|c|}
\hline $\begin{array}{c}\text { Means/Conditions } \\
\text { Category }\end{array}$ & $\begin{array}{c}\text { Variants of } \\
\text { Interpretation }\end{array}$ & Means/Conditions of Internationalization & Illustrative quotations & Freq & \\
\hline \multirow[t]{2}{*}{ Quantity } & Large & $\begin{array}{l}\text { Larger size firm. Production capacity. Business growth. Labour } \\
\text { force availability. Presence of a culture of cooperation and joint } \\
\text { production in the industry. }\end{array}$ & $\begin{array}{l}\text { When I think about going abroad I think about big firms with big } \\
\text { production capacities... They are the ones that are exporting on a } \\
\text { continuous basis... (Case } 46 \text { ) }\end{array}$ & 30 & 39 \\
\hline & Small & $\begin{array}{l}\text { Direct service to small customers abroad. Use of internet and web- } \\
\text { based services. Development of opportunities through personal } \\
\text { contacts and networking. }\end{array}$ & $\begin{array}{l}\text { One of the characteristics of our exports is that like in Brazil it does not } \\
\text { entail big volumes... We focus on specialized stores and serve them } \\
\text { directly. We don't serve big chain stores. This is a major characteristic of } \\
\text { our firm in the internal market and also abroad. (Case 42) }\end{array}$ & 9 & \\
\hline \multirow[t]{2}{*}{$\begin{array}{l}\text { Mode of } \\
\text { Competition }\end{array}$} & Low price & $\begin{array}{l}\text { Exchange rate favourability. Taxation system benevolence. Low } \\
\text { production costs. Bargaining power. Standardization of product } \\
\text { features. Brand consolidation in the domestic market (as a way to } \\
\text { avoid low price). }\end{array}$ & $\begin{array}{l}\text { To export one needs to have good price because international buyers } \\
\text { always compare your products with those produced in China... } \\
\text { (Case 1) }\end{array}$ & 32 & 42 \\
\hline & Differentiation & $\begin{array}{l}\text { Accepting small orders. Differentiating product features. Adding } \\
\text { services/support to foreign customers. Building up in the country's } \\
\text { image. Targeting small market segments. Focusing on secondary } \\
\text { (non-traditional) market/countries. }\end{array}$ & $\begin{array}{l}\text { I don't have problems with foreign customers saying that my } \\
\text { products are expensive. They recognize the value of our products } \\
\text { because they are completely different from what they have there... } \\
\text { what they like are our fabrics, modelling, and the design of our } \\
\text { products. (Case 5) }\end{array}$ & 10 & \\
\hline \multirow{3}{*}{$\begin{array}{l}\text { Difference between } \\
\text { foreign and domestic } \\
\text { operations }\end{array}$} & \multirow[t]{2}{*}{ High } & \multirow{2}{*}{$\begin{array}{l}\text { Specialized knowledge. Product change/adaptation. Adequate } \\
\text { organizational structure (international division). Qualified } \\
\text { personnel. Institutional support (government, agencies). Supply } \\
\text { chain reliability. }\end{array}$} & $\begin{array}{l}\text { Exporting requires a very different methodology and approach } \\
\text { regarding type, range and nature of products... (Case 19) }\end{array}$ & \multirow[t]{2}{*}{37} & \multirow[t]{3}{*}{49} \\
\hline & & & $\begin{array}{l}\text {...when you talk about exports, you talk about ports, airports... and it all } \\
\text { seems very bureaucratic. You know, you're going to put your product } \\
\text { here, then it may get stuck there, it may not be cleared in customs, it may } \\
\text { not arrive on the other side; this is all too scary... (Case 12) }\end{array}$ & & \\
\hline & Low & $\begin{array}{l}\text { Incorporation of foreign operations into firm's ordinary activities. } \\
\text { Use of mail and courier (door-to-door) services for international } \\
\text { delivery and logistics. Identification and access to market niche } \\
\text { segments. Adoption of an international frame of reference for } \\
\text { action. }\end{array}$ & $\begin{array}{l}\text { I started the business having my products ready and adapted for } \\
\text { international markets, even though my expectation was to sell in } \\
\text { Brazil in the beginning. Our labels were printed in three languages. } \\
\text { We applied them using transfer technology, which is a standard } \\
\text { procedure for the American and European markets... we developed } \\
\text { packing, sizes and designs that were internationally referenced... } \\
\text { Everything was made with reference to international markets. Our } \\
\text { catalogues, website, everything was in three languages from the } \\
\text { beginning... (Case 9) }\end{array}$ & 12 & \\
\hline
\end{tabular}


Table 1 (continued)

\begin{tabular}{|c|c|c|c|c|c|}
\hline $\begin{array}{l}\text { Means/Conditions } \\
\text { Category }\end{array}$ & $\begin{array}{c}\text { Variants of } \\
\text { Interpretation }\end{array}$ & Means/Conditions of Internationalization & Illustrative quotations & Freq & ency \\
\hline \multirow[t]{4}{*}{ Risk and Uncertainty } & \multirow[t]{2}{*}{ High } & \multirow{2}{*}{$\begin{array}{l}\text { Opportunism: possibility of not receiving payment for products } \\
\text { exported, low reliability of foreign suppliers, products are likely to } \\
\text { be rejected or returned for minor reasons, interest in the continuity } \\
\text { of operations. Economic (in)stability: swings in the exchange rate, } \\
\text { possibility of strikes, economic recession vs. growth. }\end{array}$} & $\begin{array}{l}\text { I worry that when you export, people may not pay for products... } \\
\text { (Case 13) }\end{array}$ & \multirow[t]{2}{*}{27} & \\
\hline & & & $\begin{array}{l}\text { I cannot cope with the risk of sending something abroad and having } \\
\text { it rejected. (Case 35) }\end{array}$ & & \\
\hline & \multirow[t]{2}{*}{ Low } & \multirow[t]{2}{*}{ Trust based relationship. } & $\begin{array}{l}\text { Our exports usually happen like this: people access our website and } \\
\text { make an order. Then I prepare everything. I contact them and they } \\
\text { make the deposit in my bank account. It's amazing how they trust } \\
\text { you! Once the money is in my account I send the products. (Case } \\
\text { 23) }\end{array}$ & 8 & 35 \\
\hline & & & $\begin{array}{l}\ldots \text { we prefer selling abroad because we receive payment in advance } \\
\text { or at sight. (Case 11) }\end{array}$ & & \\
\hline \multirow[t]{2}{*}{ Legitimacy } & Economic & Utilitarian benefits to the firm. & $\begin{array}{l}\text { It is getting difficult to produce in Brazil. It is getting more } \\
\text { expensive and China is dominating everywhere. Producing abroad } \\
\text { is a necessity. Thus you've got to find a cheaper place to } \\
\text { produce...(Case 5) }\end{array}$ & 5 & 11 \\
\hline & Social & $\begin{array}{l}\text { Effects of internationalization beyond the borders of the firm, e.g. } \\
\text { job creation, local development. }\end{array}$ & $\begin{array}{l}\text { The problem of producing abroad is that I'm committed to my } \\
\text { community. I want to produce in Brazil and help people. I know } \\
\text { that at some point I'll bring something from abroad, especially } \\
\text { those products that are more difficult to produce here. However, I } \\
\text { want to produce here. I want to know that I'm contributing to the } \\
\text { community, helping people improve their life. (Case 27) }\end{array}$ & 6 & \\
\hline
\end{tabular}


The findings suggest that while internationalization could be interpreted in terms of large quantities, low price competition, substantial difference from domestic operations, and characterized by high levels of risk and uncertainty, it could also be interpreted as encompassing the commercialization of small quantities based on price differentiation, low difference with domestic operations, and low levels of risk and uncertainty. In addition, while some judge it legitimate to assess internationalization in terms of its exclusive advantages and benefits for the firm, others consider that its effects and impacts should be appraised beyond the borders of the firm. The alternative modes of interpretation and respective means/conditions informing internationalization presented in Table 1 are now briefly summarized. Nevertheless, it is worth mentioning that the dualistic approach in which decision-makers' interpretations are portrayed in this chapter is not meant to correspond exactly to the characteristics of any one particular case. Although in many cases they do, a more appropriate understanding would be that of Weber's (1968) ideal type. In other words, it encompasses an ideaconstruct aimed at enabling understanding. Therefore, it should neither be read as evidence for the assumption that interpretation is a clear-cut dual undertaking, nor that these are the only ways of interpreting the means/conditions of internationalization.

\section{Quantities involved}

When considering the quantity or the number of pieces that typically characterizes foreign operations, decision-makers who took the view of large quantities argued that internationalization, in particular exporting, is only feasible for large firms, which have the necessary production capacity. This offered the basis for further conditioning internationalization to business growth and ultimately the availability of labour in the industry. However, those taking this view, argued that given the actual shortage of skilled people (seamstresses/tailors) in the industry, increasing production, and ultimately growing, was a difficult endeavour. Ultimately, from this perspective, internationalization was typically argued to be a difficult, if not an impossible mission to achieve. Moreover, this interpretative mode offers a plausible explanation for why some decision-makers, although favourably disposed toward internationalization, choose to only engage in it occasionally. Because they viewed internationalization through the lens of large quantities, such decision-makers may only respond to unsolicited orders from abroad if these can be accommodated within their firm's limited production capacity.

By contrast, decision-makers who adopted the rationale of small quantities argued that batches sold abroad may be as small as those sold in the domestic market. Within this interpretation, production capacity, firm size, growth, availability of labour force, and joint production did not count as necessary means/conditions of internationalization. Alternatively, it considered that selling small quantities abroad implied: (a) direct access to small customers, (b) emphasis on the use of the internet and web-based communication services, and (c) personal contacts and networking. By these means internationalization was considered to be feasible and rational despite SME's smaller size, low production capacity, the industry's shortage of labour force, or lack of adequate cooperative culture.

\section{Mode of competition}

When considering competition in foreign markets the common interpretation presumed that it is typically characterized by low prices. This understanding was based on decision-makers' views that firms from Asia, and mostly from China, are able to produce products at similar qualities to those produced in Brazil, but with much lower cost. Hence, given similar product quality, firms from Asia have a real competitive advantage over Brazilian ones. The argument of low price was typically supported by references to prior experiences, mainly encounters with foreign buyers in the context of business fairs and exhibitions, and where export opportunities were repeatedly frustrated given their inability to sell at the low price requested by foreign buyers. In this perspective, five factors set the conditions for a successful internationalization, namely: (a) favourability of the exchange rate; (b) taxation system; (c) production costs in the domestic market; (d) bargaining power; and (e) product features. 
These findings suggest that decision-makers' views of internationalization through a perspective that gives primacy to price competition may influence their strategic choices in at least two different ways. First, it offers a rationale for a purely domestic concentration or, at most, occasional internationalization. A possible explanation of this interpretation lies in the characteristics of the Brazilian market. Because the necessary means/conditions for price competition in foreign markets are taken to be external and uncontrollable (e.g. exchange rate, taxation systems, production costs), there is little that decision-makers in smaller firms can do in order to compete on such a basis. In these terms, cross-border links will tend to happen when these factors are favourable, and discontinued when unfavourable. On the other hand, price competition also presents real difficulties for smaller firms that lack the capacity for mass production and, at the same time, are not able to avoid price competition through brand strength in the domestic market. This presumes that occasional sales abroad are feasible when products can be sold without significant changes and when their price is acceptable. Nevertheless, on the view that such opportunities are rare, it would be rational for decision-makers not to commit resources to active internationalization. Second, through the lens of price-based competition, the timing of internationalization is likely to be enacted at later stages of a firm's life cycle; i.e. when a firm has grown in the domestic market and developed the means for achieving differentiation through brand recognition, ultimately considered to be necessary to avoid price competition abroad.

The alternative interpretation addressed the possibility of competing abroad by the means of differentiation. It considered that foreign sales are not necessarily dependent on low price or that achieving differentiation abroad is dependent on the prior consolidation of a brand in the domestic market. Rather, through the lens of differentiation, decision-makers enacted means/conditions for internationalization characterized by alternative ways of adding value to products or services in foreign markets. Their discourses, pointed towards a broad range of alternative means/conditions enabling differentiation in foreign markets. Inter alia, they mentioned: (a) serving small orders, (b) distinguishing a product's features, (c) adding services/support to sales, (d) benefitting from the Brazilian image, (e) focusing on specific niche markets, and (f) emphasizing non-traditional markets (countries). By these means decision-makers indicated simpler and smaller action alternatives that, as well as not being restricted to large firms, could be effective in providing differentiation abroad, for instance even before consolidation in the domestic market. The most evident implication of this interpretative mode is that it offers a rationale for early international involvement supported by an understanding that internationalization may also produce differentiation in the domestic market.

\section{Differences between foreign and domestic operations}

Through the lens of difference, decision-makers stated that procedures involved in international operations (e.g. logistics, bureaucracies, payment methodologies, control systems), are substantially distinct from those that characterize domestic operations. Customers' characteristics, tastes and preferences were argued to be equally different, such as: body characteristics, expectations for the quality of products, and fashion preferences. The perception of high cultural differences was found to include a broad range of factors. Among them, decision-makers pointed to issues such as the alternative of using jeitinho ${ }^{(2)}$ to solve problems in the domestic market and which may not be accepted abroad, different ways of approaching customers and establishing contacts, use of different languages, contrasting modes of negotiation, divergent time perception and tolerance to delays, and others. They further considered that the costs of operating abroad are different than those in domestic business - specifically, that they are higher once it implies travelling abroad, participating in international business fairs, sending sales representatives or agents abroad, establishing distribution facilities, translating catalogues and web pages, advertising, hiring specialized personnel, time for learning, and so forth.

Perception of difference between foreign and domestic operations offered the basis for decisionmakers to enact internal and external means/conditions for internationalization. Five main aspects were seen as internal requirements for internationalization, namely (a) knowledge; (b) product adaptation; (c) appropriate organizational structure; (d) qualified personnel, and (e) adequate firm size. 
Two external conditions were similarly deemed necessary: (a) the availability of institutional support; and (b) the reliability of the domestic supply chain. Overall, the means/conditions of internationalization were understood in terms of the means and conditions that justified domestic action and point out the unfeasibility of internationalization for smaller firms given their lack of resources.

The alternative view regarding differences between foreign and domestic operations was that they are not substantial. Here, differences about procedures, customers, culture and costs of operations in Brazil and abroad were deemed minor, not relevant, or usually bypassed. In perceiving low differences between foreign and domestic operations, decision-makers argued that procedures involved in foreign operations are not necessarily more difficult, bureaucratic, or complex than those that characterize domestic operations. Although differences were acknowledged, they were considered to be minor and therefore able to be easily incorporated into a firm's everyday business activities. Another important aspect found to enable decision-makers to interpret foreign and domestic operations through the lens of similarity, focused on the use of courier and door-to-door mail services for international sales. This possibility was argued to make exports easy, less costly, and further to enable the commercialization of smaller quantities. Through the lens of similarity, decision-makers also considered that selling abroad was possible with little or no product adaptation. Their view was that products sold in Brazil could equally meet customers' preferences, characteristics and tastes in foreign markets without significant alterations. This interpretation acknowledged two possibilities. On the one hand, it posited the existence of Brazilian niche markets abroad where products can be sold with the same characteristics as they are in the domestic market. One example mentioned was the case of Brazilian beachwear, a product strongly identified with the image of the country. Another considered the possibility of selling to Brazilians living abroad, or to segments where Brazilian products are in demand.

Another way in which internationalization was interpreted in regard to similarity was linked with the possibility of adopting an international frame of reference for action. By this means, they observed that products sold domestically were already following international standards of modelling, size, cut, and design, and therefore product adaptation for sales in foreign markets would be minimal. Decision-makers who considered the possibility of adopting an international frame of reference for action were further likely to perceive fewer problems when considering cultural differences in foreign operations. Moreover, the costs involved in internationalization were perceived as not being substantially higher than those demanded in domestic operations. For instance, by attempting to develop products of international standards for the domestic market, firms would have already incorporated the costs of regular travels abroad or international research as part of their ordinary costs.

These findings lead to the conclusion that although most decision-makers were likely to interpret the means/conditions of internationalization through the lens of high difference, an alternative interpretation through the lens of similarity is also possible.

\section{Risk and uncertainty}

The interpretation of risk and uncertainty in foreign operations was to a great extent linked to decision-makers' views about differences and similarities between foreign and domestic operations. Interpreting internationalization as a course of action that encompasses high levels of risk and uncertainty was the most frequent view among decision-makers. It encompassed two major means/conditions characterizing foreign operations: opportunism and economic instability. Opportunism refers to decision maker's understanding that foreign counterparts are likely to act in a misleading, distorting, disguising or confusing way. On this view they argued that when operating abroad it is difficult to gauge whether the external party will act in an opportunistic or trustful way. Therefore, the prudent behaviour should presume that external agents act opportunistically. Four major aspects were considered here: (a) the possibility of not receiving payment for products exported; (b) having products rejected and returned by foreign buyers; (c) uncertainty about continuity of operations; and (d) concerns about the quality of products/services when sourcing abroad. Economic 
instability was also acknowledged as a major source of risk and uncertainty in foreign operations. Here decision-makers mainly addressed: (a) the levels of variance in the exchange rate; (b) the possibility of strikes in relevant services in the domestic market; and (c) the possibility of economic crises and downturns.

Although less frequent, the alternative interpretation encompassed the view that levels of risk and uncertainty in foreign operations can be lower than those that characterize domestic operations. Within this perspective, contrary to the view of opportunism, the means/conditions of internationalization were mainly interpreted on the basis of trust and could be grasped when decisionmakers assessed the risk of not receiving payment when selling abroad. Here, some decision-makers argued that foreign sales are characterized by much lower risk than operations in the domestic market, especially in relation to receiving payment for sales. Therefore, selling abroad becomes particularly favourable for smaller firms. They contended that foreign counterparts act on the basis of trust and typically make payment for sales in advance or against delivery. This was typically contrasted to how payment for sales in the domestic market are made, namely in two or three instalments after the delivery of products.

\section{Legitimacy}

Through this lens decision-makers interpreted internationalization in relation to its wider social impacts, and whether these were acceptable vis-à-vis norms and values orienting accepted behaviour, particularly within their social groups of reference. This was most prominent when decision-makers considered the alternative of importing raw materials, outsourcing and investing abroad. The understanding presumed that importing materials, or outsourcing production to a foreign country would not manifest commitment to the development of the local economy. Nevertheless, social legitimacy was equally found to influence strategic choices regarding the possibility of exports. This understanding was mainly based on the view that selling abroad demands a strategy of low cost and price and in so doing is based on the exploitation of local human labour. Decision-makers adopting this view questioned the social legitimacy of exports and even the efforts of government and agencies attempting to increase the number of exporting SMEs.

The alternative interpretation consisted of an economic view of legitimacy. It presumed that strategic choices in internationalization should be chiefly assessed in terms of profit-making benefits for the firm. Hence, this view distinguishes from social legitimacy on the basis that it takes the individualized firm as its point of reference, and considers that pursuing profits is the legitimate aim of internationalization. The rationale takes the firm as its point of reference and presumes that where internationalization is imperative for the economic survival of the firm, it entails a legitimate and expected course of action, despite eventual social consequences such as reducing the number of jobs in the local context. This contrasts with the tenets of social legitimacy that offer grounds for disregarding and avoiding internationalization.

\section{Interpretative modes and action choices in internationalization}

The final stage of the analysis applied a quantitative exploration to the qualitative data. We questioned whether different modes of interpretation concerning the means and conditions of international involvement were associated with action choices in internationalization. This approach is essentially exploratory and is not intended to test relationships hypothesized a priori, but rather to clarify findings, triangulate and enhance their validity, and point out areas for further investigation.

The analysis is based on the binary coding of the interview responses and considers whether a particular view about the means/conditions of internationalization occurred (1) or did not occur (0). It tested the linear correlation between action choices regarding domestic, occasional and active internationalization and the means/conditions assigned to it. Active international involvement is positively correlated (in order of strength) with the following understandings about the means/conditions of internationalization: (a) that it entails operations involving small quantities $(r=$ 
$0.56 \mathrm{p}<0.01$ ); (b) that the legitimacy of action choices in internationalization are supposed to be considered from an economic perspective $(r=0.51 \mathrm{p}<0.01)$; (c) that differences between foreign and domestic operations are low $(r=0.44 \mathrm{p}<0.01)$; and (d) that competition in foreign markets is based on differentiation $(r=0.39 \mathrm{p}<0.01)$. These findings are in line with the qualitative observations made earlier.

Occasional internationalization was found to be positively correlated with the understanding that competition in foreign markets is based on price $(\mathrm{r}=0.40 \mathrm{p}<0.01)$. This is in line with the observation that price competition in foreign markets is dependent on the favourability of the exchange rate, the benevolence of the taxation system, production costs and so on. The action-choice to remain purely domestic was found to be negatively correlated with the understanding that international involvement entails price competition and small quantities. This suggests that a belief that internationalization requires more than price competitiveness and that it cannot be achieved by selling small quantities encourages the choice to remain purely domestic.

In short, although there is also the question of precedence in correlation analysis, i.e. whether interpretation precedes action or vice versa, these findings support the conclusion that different understandings given to the means/conditions of internationalization are associated with different action choices in that direction.

\section{Discussion}

Our findings support the contention that situational factors (internal and external) do not directly affect internationalization. It thus corroborates the tenets of an interpretative view of organizational action (Barr, Sitimpert, \& Huff, 1992; Daft \& Weick, 1984; Kabanoff \& Brown, 2008). With reference to the action of internationalizing, the study demonstrated that decision-makers might interpret the means/conditions considered in this process in substantially different ways. This has important implications for understanding and theorizing internationalization phenomena.

First it indicates that internationalization is more complex than conventional theorizing has considered. Our findings show that the criteria and parameters considered when decision-makers choose about internationalization are not as unambiguous as typically portrayed in the specialized literature. Hence, what for some decision-makers may be considered an opportunity to internationalize (Johanson \& Vahlne, 1977, 2009), an advantage enabling foreign operations (Dunning, 1988; Hymer, 1976), or a transaction cost driving internalization (Buckley \& Casson, 1976); others may simply not take it into account. Put differently, our findings suggest that before presuming that firm's situational characteristics determine internationalization, it is imperative to recognize that decision-makers have to interpret their situation. On the premise that interpretation reflects the capacity of decision-makers to create and assign meanings to criteria and parameters included in the choice process, our findings corroborate Child's (1997) argument that external and internal factors should be taken as interpretative referents in the organizational choice process.

Second, our findings suggest that the failure within prevailing theorizing to recognize that situational forces are filtered by managerial interpretation, accounts for the limited explanatory power of variables that are conventionally investigated. They indicate that on the basis of different interpretative modes, decision-makers could rationally enact different choices regarding their firms' international involvement. The findings further indicated that decision-makers could give attention to different situational means and conditions when considering internationalization, and they can equally interpret similar ones in different ways. This implies that even if one assumes that internationalization is oriented towards a single goal such as profit maximization (Buckley \& Casson, 2009), decisionmakers may not recognize the means/conditions of international involvement in a unique or single way. In these terms our findings indicate that interpretation relativizes criteria and parameters considered by decision-makers when making choices in internationalization. We believe this is an 
important recognition to be considered in future theorizing in the field. It implies the need to consider that even in circumstances where decision-makers share similar situational characteristics, there is still space for action-choice variance on the basis of how they make sense of the means/conditions of internationalization.

Third, by these means interpretation enables us to introduce the possibility of agency and choice within determinist tendencies of mainstream theorizing on internationalization (Hutzschenreuter, Pedersen, \& Volberda, 2007). As Alexander (1988) asserts, although interpretation is about reproducing or typifying new information into pre-existent meaningful categories, when interpreting the world, actors can always do this in somewhat different and imaginative ways. This is not to assume an extreme individualist perspective which presumes that managers can freely enact the world in their minds as they wish. Rather this contention requires an epistemological position capable of recognizing and accounting for the inextricably inter-dependence of human beings and their world. Put differently, we assert the need to move internationalization theorizing beyond the positivist position that considers reality and person as objective and independent domains. Here we join the plea for an ontological and epistemological renewal in the field (Sullivan, 1998; Sullivan \& Daniels, 2008; Toyne \& Nigh, 1998). What is envisioned here is that at the same time reality is dependent upon subjective interpretation, it is also objective in the sense that it is inter-subjectively negotiated, shared and sustained (Berger \& Luckmann, 1966; Sandberg \& Targama, 2007). This understanding considers that social reality transcends and exceeds the individual subject. Such an ontological position thus occupies a middle ground between realism, which assumes reality as objective and independent, and subjectivism, which assumes that knowledge about reality is a nothing more than an arbitrary subjective construction. Philosophically, this position has been advanced in some constructivist approaches such as the one proposed by Glasersfeld (2002) and is similar to the one advocated in Child's (1997) development of the strategic choice perspective.

Fourth, our findings indicate that different modes of interpretation are likely to influence strategic choices in particular directions while ignoring others. We observed that in the case of SMEs in the Paraná clothing industry, active internationalization is likely to be enacted when the means/conditions of international involvement are interpreted in terms of small quantities, economic legitimacy, low differences between foreign and domestic operations, and differentiation-based competition. Alternatively, when decision-makers interpret foreign sales from the viewpoint of price competition, they are likely to adopt an occasional approach to internationalization.

Finally, by highlighting and pointing out the role of interpretation, our study suggests that when attempting to comprehensively understand internationalization, proximity to practitioners is essential. On the basis of our findings we contend that internationalization should be defined, measured, and studied in a way that is meaningful and relevant to those who make decisions in organizations. We believe that theorizing about internationalization must be based upon and reflect how practitioners understand this phenomenon and make sense of their business situation and practice.

\section{Conclusion}

In this study we investigated how decision-makers in smaller firms interpret the means and conditions of internationalization, and how different modes of interpretation are likely to inform action choices in this process. The results indicated that both interpretation changes the criteria and parameters by which rational choices in internationalization are made; as well as that particular meanings given to the means-conditions of internationalization are likely to orient choice in different ways. Although this may not sound new, we contend that the role of interpretation has been neglected in mainstream theorizing. Nevertheless, its recognition has important contributions for the advance of internationalization theory and practice. 
For theory, our findings indicate that a comprehensive explanation of internationalization on the basis of firm, managerial, environmental and other situational characteristics as typically portrayed in dominant theorizing is likely to be inconclusive without the qualification of how decision-makers interpret both internationalization as well as their situation (i.e. resources and environment). The findings of the present investigation indicated that the meaning of internationalization for decisionmakers should not be regarded as irrelevant. This recognition suggests that internationalization is much more complex than conventional theorizing has considered, and that further research considering the role of interpretation on internationalization is necessary.

In particular, by showing that the meanings given to the means-conditions of internationalization vary, our study suggests that, rather than encompassing an objective reality, internationalization is informed by an inter-subjectively negotiated, shared and sustained reality. On the one hand, this suggests that proximity with practitioners is pivotal in order to account comprehensively for their interpretations when studying internationalization. On the other hand, it contrasts with dominant theorizing that considers reality and person as objective and independent domains. Our findings contribute to current research by offering evidence that choices in internationalization are informed by inter-subjective meanings encapsulated into particular time and space of the life-world and in so doing join the plea for a renewed ontology and epistemology for the theorizing in the field.

When considering managerial practice, our study contributes by suggesting that although internationalization is typically associated with contextual variables such as firm size, age, prior international experience, knowledge of foreign languages and others, the relevance and role of these variables are likely to vary depending on how internationalization is understood. Our findings indicated that at the same time as internationalization can be enacted in terms of selling large quantities, price based competition, risk and uncertainty, and being substantially different from operations in the domestic market, it can also be alternatively enacted in terms of selling small quantities, being based on differentiation, and as largely similar to domestic operations. This has important implications for practice, since depending on how internationalization is interpreted, different firm and managerial attributes may be understood as requirements for positively acting in that direction. Notably, while the first interpretation is likely to inform choice towards domestic action, the later is likely to favour international involvement.

This study is not without its limitations. First, it is important to recognize that interview based research involves social and linguistic complexities that in many ways aggravate the possibility of bias, both on the part of the interviewee as well as that of the interviewer (Alvesson, 2003). In particular, we recognize that findings emerging out of the qualitative analysis are not completely free from the researchers' own interpretations when attempting to summarize, reduce, and reconstruct the data. To deny this is to assume a positivist epistemology which is not consistent with the assumptions on which this study stands. Nevertheless, this must not be taken as excuse for lack of methodological rigour. To minimize bias and enhance reliability of the analysis, the process of qualitative data analysis was carefully conducted, emerging categories were repeatedly cross checked with raw data, alternative explanations were built and critically evaluated, themes and codes were cross-checked and audited by external coders. Second, categories of meaning are not expected to be exhaustive, and their generalization to other fields should be made with caution. Third, our study raises, but does not resolve, the question of causality. Further research should consider both how different interpretative modes inform action choices on internationalization and whether action choices in turn cause interpretations to be modified in the light of experience with those chosen actions. This will require a complex longitudinal design that was beyond the scope of the present study. Finally, our study was focused on a particular industry in a single country. There is clearly scope for further research to map out interpretative modes that may be institutionalized in different organizational fields, sectors or industries, and how they inform choices on internationalization. This approach is likely to be of particular interest and relevance for policy making in the field.

Received 21 November 2011; received in revised form 11 May 2012. 


\section{Notes}

\footnotetext{
${ }^{1}$ The interview guide is available on request.

${ }^{2}$ The jeitinho is a peculiar characteristic of the Brazilian culture (Barbosa, L. (1992). O jeitinho brasileiro. Rio de Janeiro: Campus). Although it constitutes a rather ambiguous and multifaceted term, it typically refers to a social practice by which someone attempts to reach something desired in spite of contrary determinations such as laws, orders, norms or rules (Holanda, S. B. (1995). Raízes do Brasil. São Paulo: Companhia das Letras). It is conventionally used to circumvent difficulties that otherwise would make impossible for the person to reach his/her aim without breaking norms and laws (Vieira, C. A., Costa, F. L. D., \& Barbosa, L. (1982). O jeitinho brasileiro como um recurso de poder. Revista de Administração Pública, 16(2), 5-31).
}

\section{References}

Acedo, F. J., \& Florin, J. (2006). An entrepreneurial cognition perspective on the internationalization of SMEs. Journal of International Entrepreneurship, 4(1), 49-67. doi: 10.1007/s10843-0060482

Aharoni, Y. (1966). The foreign investment decision process. Boston: Division of Research, Graduate School of Business Administration, Harvard University.

Alexander, J. C. (1988). Action and its environments: toward a new synthesis. New York: Columbia University Press.

Alvesson, M. (2003). Beyond neopositivists, romantics, and localists: a reflexive approach to interviews in organizational research. Academy of Management Review, 28(1), 13-33. doi: 10.5465/AMR.2003.8925191.

Andersson, S. (2000). The internationalization of the firm from an entrepreneurial perspective. International Studies of Management \& Organization, 30(1), 63-92.

Barr, P. S., Sitimpert, J. L., \& Huff, A. S. (1992). Cognitive change, strategic action, and organizational renewal. Strategic Management Journal, 13(S1), 15-36. doi: $10.1002 / \mathrm{smj} .4250131004$

Bartunek, J. M. (1984). Changing interpretive schemes and organization restructuring: the example of a religious order. Administrative Science Quarterly, 29, 355-372.

Bell, J., McNaughton, R., Young, S., \& Crick, D. (2003). Towards an integrative model of small firm internationalisation. Journal of International Entrepreneurship, 1(4), 339-362. doi: 10.1023/A:1025629424041

Berger, P. L., \& Luckmann, T. (1966). The social construction of reality: a treatise in the sociology of knowledge. London: Penguin Books.

Bilkey, W. J., \& Tesar, G. (1977). The export behavior of smaller-sized Wiscosin manufacturing firms. Journal of International Business Studies, 8(1), 93-98. doi:10.1057/palgrave.jibs.8490783

Blumer, H. (1998). Symbolic interactionism. Berkeley: University of California Press.

Boddewyn, J. (1997). The conceptual domain of international business: territory, boundaries, and levels. In B. Toyne \& D. Nigh (Eds.), International business: an emerging vision (Chap. 2, pp. 50-61). Columbia: University of South Carolina Press. 
Bourgeois, L. J., III, \& Eisenhardt, K. M. (1988). Strategic decision processes in high velocity environments: four cases in the microcomputer industry. Management Science, 34(7), 816-835. doi: $10.1287 / \mathrm{mnsc} .34 .7 .816$

Buckley, P., \& Casson, M. (1976). The future of the multinational enterprise. New York: Holmes \& Meier Publishers.

Buckley, P. J., \& Casson, M. C. (2009). The internalisation theory of the multinational enterprise: a review of the progress of a research agenda after 30 years. Journal of International Business Studies, 40(9), 1563-1580. doi:10.1057/jibs.2009.49

Burgel, O., Fier, A., Licht, G., \& Murray, G. (2004). The internationalisation of young high-tech firms: an empirical analysis in Germany and the United Kingdom. Heidelberg and London: Physica-Verlag and Springer.

Burgess, R. G. (1984). In the field: an introduction to field research. London: Routledge.

Calof, J. L., \& Beamish, P. W. (1995). Adapting to foreign markets: explaining internationalization. International Business Review, 4(2), 115-131. doi: 10.1016/0969-5931(95)00001-G

Cavusgil, S. T. (1980). On the internationalization process of firms. European Research, 8(6), 273281.

Child, J. (1997). Strategic choice in the analysis of action, structure, organizations and environment: retrospect and prospect. Organization Studies, 18(1), 43-76. doi: 10.1177/017084069701800104

Child, J., \& Rodrigues, S. B. (2005). The internationalization of Chinese firms: a case for theoretical extension? Management and Organization Review 1(3), 381-410. doi: 10.1111/j.17408784.2005.0020a.x

Corbin, J. M., \& Strauss, A. L. (2008). Basics of qualitative research: techniques and procedures for developing grounded theory. Los Angeles: Sage Publications, Inc.

Coviello, N., \& Munro, H. (1997). Network relationships and the internationalisation process of small software firms. International Business Review, 6(4), 361-386. doi: 10.1016/S09695931(97)00010-3

Daft, R. L., \& Weick, K. E. (1984). Toward a model of organizations as interpretation systems. Academy of Management Review, 9(2), 284-295. doi: 10.5465/AMR.1984.4277657

Dunning, J. H. (1980). Toward an eclectic theory of international production: some empirical tests. Journal of International Business Studies, 11(1), 9-31. doi:10.1057/palgrave.jibs.8490593

Dunning, J. H. (1988). The eclectic paradigm of international production: a restatement and some possible extensions. Journal of International Business Studies, 19(1), 1-31. doi:10.1057/palgrave.jibs. 8490372

Eisenhardt, K. M. (1989). Building theories from case study research. The Academy of Management Review, 14(4), 532-550. doi:10.2307/258557

Field, A. P. (2005). Discovering statistics using SPSS. Los Angeles; London: SAGE.

Gioia, D. A., \& Chittipeddi, K. (1991). Sensemaking and sensegiving in strategic change initiation. Strategic Management Journal, 12(6), 433-448. doi: 10.1002/smj.4250120604

Gioia, D. A., \& Thomas, J. B. (1996). Identity, image, and issue interpretation: sensemaking during strategic change in academia. Administrative Science Quarterly, 41(3), 370-430. 
Glaser, B. G., \& Strauss, A. L. (1967). The discovery of grounded theory: strategies for qualitative research. Chicago: Aldine Pub. Co.

Glasersfeld, E. V. (2002). Radical constructivism: a way of knowing and learning. London: Routledge/Falmer.

Hitt, M. A., Bierman, L., Uhlenbruck, K., \& Shimizu, K. (2006). The importance of resources in the internationalization of professional service firms: the good, the bad, and the ugly. Academy of Management Journal, 49(6), 1137-1157. doi: 10.5465/AMJ.2006.23478217

Hutzschenreuter, T., Pedersen, T., \& Volberda, H. W. (2007). The role of path dependency and managerial intentionality: a perspective on international business research. Journal of International Business Studies, 38(7), 1055-1068. doi:10.1057/palgrave.jibs.8400326

Hymer, S. H. (1976). The international operations of national firms: a study of direct foreign investment. Cambridge, Mass, London: M.I.T. Press.

Johanson, J., \& Mattsson, L.-G. (1988). Internationalization in industrial systems: a network approach. In P. J. Buckley \& P. N. Ghauri (Eds.), The internationalization of the firm: a reader (pp. 303321). London: Academic Press.

Johanson, J., \& Vahlne, J.-E. (1977). The internationalization process of the firm: a model of knowledge development and increasing foreign market commitments. Journal of International Business Studies, 8(1), 23-32. doi:10.1057/palgrave.jibs.8490676

Johanson, J., \& Vahlne, J.-E. (1990). The mechanism of internationalisation. International Marketing Review, 7(4), 11-24. doi: 10.1108/02651339010137414

Johanson, J., \& Vahlne, J.-E. (2006). Commitment and opportunity development in the internationalization process: a note on the uppsala internationalization process model. Management International Review, 46(2), 165-178. doi:10.1007/s11575-006-0043-4

Johanson, J., \& Vahlne, J.-E. (2009). The uppsala internationalization process model revisited: from liability of foreignness to liability of outsidership. Journal of International Business Studies, 40(9), 1411-1431. doi: 10.1057/jibs.2009.24

Kabanoff, B., \& Brown, S. (2008). Knowledge structures of prospectors, analyzers, and defenders: content, structure, stability, and performance. Strategic Management Journal, 29(2), 149-171. doi: $10.1002 /$ smj.644

Kogut, B., \& Zander, U. (1993). Knowledge of the firm and the evolutionary theory of the multinational corporation. Journal of International Business Studies, 24(4), 625-645. doi:10.1057/palgrave.jibs. 8490248

Krippendorff, K. (2004). Content analysis: an introduction to its methodology. Thousand Oaks; London and New Dehli: Sage.

Legard, R., Keegan, J., \& Ward, K. (2003). In-depth interviews. In J. Ritchie \& J. Lewis (Eds.), Qualitative research practice: a guide for social science students and researchers (Chap. 6, pp. 138-169). London: Sage.

Lim, J.-S., Sharkey, T. W., \& Kim, K. I. (1991). An empirical test of an export adoption model. Management International Review, 31(1), 51-62.

Manolova, T. S., Brush, C. G., Edelman, L. F., \& Greene, P. G. (2002). Internationalization of small firms: personal factors revisited. International Small Business Journal, 20(1), 9-31. doi: $10.1177 / 0266242602201003$ 
McDougall, P. P., Shane, S., \& Oviatt, B. M. (1994). Explaining the formation of international new ventures: the limits of theories from international business research. Journal of Business Venturing, 9(6), 469-487. doi: 10.1016/0883-9026(94)90017-5

Miles, M. B., \& Huberman, M. A. (1994). Qualitative data analysis: an expanded sourcebook. London: Sage.

Oviatt, B. M., \& McDougall, P. P. (2005). Defining international entrepreneurship and modeling the speed of internationalization. Entrepreneurship Theory and Practice, 29(5), 537-554. doi: 10.1111/j.1540-6520.2005.00097.x

Parsons, T. (1968). The structure of social action (Vol. 1). New York: Free Press.

Peng, M. W. (2001). The resource-based view and international business. Journal of Management, 27(6), 803-829. doi: 10.1177/014920630102700611

Pettigrew, A. (1990). Longitudinal field research on change: theory and practice. Organization Science, 1(3), 267-292. doi: 10.1287/orsc.1.3.267

Reid, S. D. (1981). The decision-maker and export entry and expansion. Journal of International Business Studies, 12(2), 101-112. doi:10.1057/palgrave.jibs.8490581

Ritchie, J., Lewis, J., \& Elam, G. (2003). Designing and selecting samples. In J. Ritchie \& J. Lewis (Eds.), Qualitative research practice: a guide for social science students and researchers (pp. 77-108). London: Sage.

Rocha, A. D. (2003). Por que as empresas brasileiras não se internacionalizam? In A. D. Rocha (Ed.), As novas fronteiras: a multinacionalização das empresas Brasileiras (pp. 13-28). Rio de Janeiro: Mauad.

Sandberg, J., \& Targama, A. (2007). Managing understanding in organizations. London: Sage.

Schutz, A. (1972). The phenomenology of the social world. London: Heinemann Educational.

Seale, C., \& Silverman, D. (1997). Ensuring rigour in qualitative research. European Journal of Public Health, 7(4), 379-384. doi: 10.1093/eurpub/7.4.379

Seifert, R. E., \& Machado-da-Silva, C. L. (2007). Environment, resources and interpretation: influences in the internationalization strategies of the food industry in Brazil. Brazilian Administration Review, 4(2), 40-63. doi: 10.1590/S1807-76922007000200004

Selltiz, C., Wrightsman, L. S., \& Cook, S. W. (1976). Research methods in social relations. New York: Holt, Rinehart and Winston.

Silverman, D. (1978). The theory of organisations: a sociological framework: Open University.

Silverman, D. (2006). Interpreting qualitative data: methods for analyzing talk, text, and interaction. London: Sage.

Spender, J.-C. (1998). The dynamics of individual and organizational knowledge. In C. Eden \& J.-C. Spender (Eds.), Managerial and organizational cognition (pp. 13-39). London: Sage.

Sullivan, D. (1998). The ontology of international business: a comment on international business: an emerging vision. Journal of International Business Studies, 29(4), 877-885. doi:10.1057/palgrave.jibs.8490057

Sullivan, D. P., \& Daniels, J. D. (2008). Innovation in international business research: A call for multiple paradigms. Journal of International Business Studies, 39(6), 1081-1090. doi:10.1057/palgrave.jibs. 8400400 
Toyne, B., \& Nigh, D. (1998). A more expansive view of international business. Journal of International Business Studies, 29(4), 863-875. doi:10.1057/palgrave.jibs.8490056

Weber, M. (1968). Economy and society: an outline of interpretive sociology. New York: Bedminster Press.

Weick, K. E. (1969). The social psychology of organizing. Reading, MA: Addison-Wesley.

Yeung, H. W.-C. (1995). Qualitative personal interviews in international business research: some lessons from a study of Hong Kong Transnational Corporations. International Business Review, 4(3), 313-339. doi: 10.1016/0969-5931(95)00012-O

Yin, R. K. (2003). Case study research: design and methods. London: Sage.

Zahra, S. A., Korri, J. S., \& Yu, J. (2005). Cognition and international entrepreneurship: implications for research on international opportunity recognition and exploitation. International Business Review, 14(2), 129-146. doi: 10.1016/j.ibusrev.2004.04.005 


\section{APPENDIX}

\section{Profile of Firms Included in the Sample}

\begin{tabular}{|c|c|c|c|c|c|c|c|c|c|c|c|}
\hline \multirow[t]{2}{*}{ Firm Code } & \multirow{2}{*}{$\begin{array}{c}\text { Year of } \\
\text { Foundation }\end{array}$} & \multirow[t]{2}{*}{ Size $^{a}$} & \multicolumn{5}{|c|}{ Cross Border Links } & \multirow{2}{*}{$\begin{array}{c}\text { International } \\
\text { Involvement }\end{array}$} & \multirow{2}{*}{$\begin{array}{c}\text { Prior } \\
\text { International } \\
\text { Experience }\end{array}$} & \multirow{2}{*}{$\begin{array}{c}\text { Export } \\
\text { Intention } \\
(\text { Index })^{\mathrm{c}}\end{array}$} & \multirow{2}{*}{$\begin{array}{c}\text { K. Foreign } \\
\text { Languages } \\
\text { (Index) }^{d}\end{array}$} \\
\hline & & & IMP & I-EX & D-EX & I-CO & FDI & & & & \\
\hline Case 1 & 1995 & Micro & 5 & & 8 & & & Occasional & No & 4.33 & 3.00 \\
\hline Case2 & 1998 & Micro & & 2 & 5 & & 6 & Active & Yes & 3.67 & 3.67 \\
\hline Case 3 & 2000 & Small & & & & & & Domestic & No & NA & NA \\
\hline Case 4 & 2005 & Micro & & & & & & Domestic & No & 5.67 & 2.00 \\
\hline Case 5 & 2005 & Micro & & & 2 & & & Active & No & 6.00 & 3.67 \\
\hline Case 6 & 2001 & Small & & & 4 & 4 & & Occasional & Yes & 7.00 & 5.00 \\
\hline Case 7 & 2005 & Micro & 2 & & 2 & & & Occasional & Yes & 5.33 & 6.00 \\
\hline Case 8 & 1999 & Medium & & & & & & Domestic & No & 2.67 & 1.67 \\
\hline Case 9 & 2006 & Micro & 0 & & 0 & & & Active & Yes & 6.67 & 6.00 \\
\hline Case 10 & 2005 & Micro & & 3 & & & & Active & Yes & 6.00 & 3.33 \\
\hline Case 11 & 1994 & Small & & & NA & & & Occasional & No & NA & NA \\
\hline Case 12 & 1989 & Medium & & & & & & Domestic & No & 3.00 & 1.00 \\
\hline Case 13 & 2005 & Small & & & & & & Domestic & No & 4.67 & 4.00 \\
\hline Case 14 & 2004 & Micro & & & & & & Domestic & No & 3.00 & 1.33 \\
\hline Case 15 & 1993 & Small & 5 & & 11 & & & Occasional & No & 3.00 & 2.33 \\
\hline Case 16 & 1997 & Micro & & & 8 & & & Active & No & 7.00 & 3.00 \\
\hline Case 17 & 1998 & Micro & & & & & & Domestic & No & NA & NA \\
\hline Case 18 & 2001 & Medium & & & & & & Domestic & No & NA & NA \\
\hline Case 19 & 1986 & Small & & 20 & 20 & & & Occasional & No & 5.00 & 2.33 \\
\hline Case 20 & 2004 & Small & & & 1 & & 1 & Active & Yes & NA & NA \\
\hline Case 21 & 1994 & Medium & & & & & & Domestic & No & NA & NA \\
\hline Case 22 & 1990 & Micro & & & & & & Domestic & No & 1.00 & 3.00 \\
\hline Case 23 & 2002 & Small & & & 4 & & & Active & No & 5.33 & 2.33 \\
\hline Case 24 & 1999 & Small & 0 & 0 & & 0 & & Active & Yes & 3.00 & 6.33 \\
\hline Case 25 & 2000 & Micro & & & & & & Domestic & No & 3.00 & 2.00 \\
\hline Case 26 & 1994 & Medium & 12 & & 1 & & & Active & Yes & 4.67 & 4.00 \\
\hline Case 27 & 2006 & Micro & & & & & & Domestic & Yes & 7.00 & 3.67 \\
\hline Case 28 & 1976 & Small & 29 & & & & & Occasional & No & 2.00 & 3.00 \\
\hline Case 29 & 1992 & Small & & & 13 & & & Occasional & No & 6.00 & 5.00 \\
\hline Case 30 & 1995 & Small & & & 8 & & & Occasional & No & 5.00 & 3.67 \\
\hline Case 31 & 1994 & Medium & 3 & & 8 & & 11 & Active & No & 6.33 & 6.33 \\
\hline Case 32 & 2002 & Small & & & & & & Domestic & No & NA & NA \\
\hline Case 33 & 1979 & Medium & & & NA & & & Occasional & No & NA & NA \\
\hline Case 34 & 1981 & Micro & & & & & & Domestic & No & 7.00 & 1.00 \\
\hline Case 35 & 2008 & Micro & & & & & & Domestic & Yes & 6.33 & 5.00 \\
\hline Case 36 & 1985 & Micro & & & 21 & & & Occasional & No & NA & 4.33 \\
\hline
\end{tabular}




\begin{tabular}{|c|c|c|c|c|c|c|c|c|c|c|}
\hline \multirow[t]{2}{*}{ Firm Code } & \multirow{2}{*}{$\begin{array}{c}\text { Year of } \\
\text { Foundation }\end{array}$} & \multirow[t]{2}{*}{ Size $^{\mathrm{a}}$} & \multicolumn{4}{|c|}{ Cross Border Links } & \multirow{2}{*}{$\begin{array}{l}\text { International } \\
\text { Involvement }\end{array}$} & \multirow{2}{*}{$\begin{array}{c}\text { Prior } \\
\text { International } \\
\text { Experience }\end{array}$} & \multirow{2}{*}{$\begin{array}{c}\text { Export } \\
\text { Intention } \\
(\text { Index })^{\mathrm{c}}\end{array}$} & \multirow{2}{*}{$\begin{array}{c}\text { K. Foreign } \\
\text { Languages } \\
{(\text { Index })^{\mathbf{d}}}^{\text {and }}\end{array}$} \\
\hline & & & IMP & I-EX & D-EX & I-CO FDI & & & & \\
\hline Case 37 & 1993 & Small & & & & & Domestic & No & 4.00 & 1.00 \\
\hline Case 38 & 1998 & Medium & & & 9 & & Occasional & No & 6.00 & 2.33 \\
\hline Case 39 & 1992 & Medium & 16 & 14 & 13 & & Active & No & 3.67 & 2.67 \\
\hline Case 40 & 1978 & Small & & & 25 & & Occasional & No & NA & NA \\
\hline Case 41 & 1977 & Medium & 24 & & 30 & & Active & No & NA & NA \\
\hline Case 42 & 1979 & Medium & 21 & 22 & 16 & 24 & Active & No & 5.33 & 3.67 \\
\hline Case 43 & 2001 & Micro & & & & & Domestic & No & 1.33 & 1.33 \\
\hline Case 44 & 2001 & Medium & & & & & Domestic & No & 4.00 & 2.67 \\
\hline Case 45 & 1997 & Small & & & & & Domestic & No & 1.00 & 3.00 \\
\hline Case 46 & 1983 & Micro & & & & & Domestic & No & 1.00 & 1.67 \\
\hline Case 47 & 1986 & Micro & 2 & 1 & & & Occasional & No & NA & NA \\
\hline Case 48 & 1990 & Small & 8 & 13 & 13 & & Occasional & No & 2.00 & 2.67 \\
\hline Case 49 & 1997 & Small & & & & & Domestic & No & 3.33 & 1.00 \\
\hline Case 50 & 1992 & Small & & 12 & 11 & & Active & No & 1.33 & 3.00 \\
\hline Case 51 & 1995 & Small & & & & & Domestic & No & 1.67 & 2.67 \\
\hline Case 52 & 1994 & Micro & & & 12 & & Active & Yes & 3.00 & 4.00 \\
\hline Case 53 & 1996 & Micro & & & 9 & & Occasional & No & 3.67 & 2.00 \\
\hline Case 54 & NA & Micro & & & & & Domestic & No & NA & NA \\
\hline Case 55 & 1987 & Medium & & & 17 & & Active & No & 4.00 & 2.33 \\
\hline Case 56 & 2005 & Micro & & & & & Domestic & No & 5.67 & 5.00 \\
\hline Case 57 & 2000 & Small & 5 & & 3 & & Active & No & 5.00 & 3.33 \\
\hline Case 58 & 2004 & Micro & & & 2 & & Occasional & No & 5.67 & 4.33 \\
\hline
\end{tabular}

${ }^{a}$ Defined in accordance with the number of employees: Micro < 20, Small $20-99$, Medium 100-499; ${ }^{\text {b }}$ Types of cross border link established since foundation: IMP = Import, I-EX= Indirect Export, D-EX=Direct Export, I-CO=International Contract, FDI=Foreign Direct Investment. Numbers refer to years between a firm's foundation and the establishment of cross border links for the first time; ${ }^{\mathrm{c}}$ Composite index of three 7 point scales for the degree of knowledge of English, Spanish and Other Language available among the management team; ${ }^{\mathrm{d}}$ Composite index of three 7 point scales considering: (1) interest in exports; (2) likelihood of exporting to new markets in the following three years; and (3) how important exporting is for the firm to achieve its objectives. 